\title{
Reaction Behavior of Cellulose in the Homogeneous Esterification of Bagasse Modified with Phthalic Anhydride in Ionic Liquid 1-Allyl-3-methylimidazium Chloride
}

\author{
Hui-Hui Wang, ${ }^{1}$ Xue-Qin Zhang, ${ }^{1}$ Piao Long, ${ }^{1}$ Ai-Ping Zhang, \\ Chuan-Fu Liu, ${ }^{1}$ and Run-Cang Sun ${ }^{3}$ \\ ${ }^{1}$ State Key Laboratory of Pulp and Paper Engineering, South China University of Technology, Guangzhou 510640, China \\ ${ }^{2}$ College of Materials and Energy, Guangdong Key Laboratory for Innovative Development and Utilization of Forest Plant Germplasm, \\ South China Agricultural University, Guangzhou 510642, China \\ ${ }^{3}$ Beijing Key Laboratory of Lignocellulosic Chemistry, Beijing Forestry University, Beijing 100083, China
}

Correspondence should be addressed to Chuan-Fu Liu; chfliu@scut.edu.cn

Received 3 June 2016; Revised 11 August 2016; Accepted 31 August 2016

Academic Editor: Antje Potthast

Copyright @ 2016 Hui-Hui Wang et al. This is an open access article distributed under the Creative Commons Attribution License, which permits unrestricted use, distribution, and reproduction in any medium, provided the original work is properly cited.

\begin{abstract}
In order to elucidate the reaction behavior of cellulose component in bagasse, the homogeneous phthalation of bagasse was investigated comparatively with the isolated cellulose in 1-allyl-3-methylimidazium chloride (AmimCl) with phthalic anhydride (PA) at the dosage of $10-50 \mathrm{mmol} / \mathrm{g}$. The phthalation degrees of bagasse and the isolated cellulose were in the range of $5.66 \%$ to $22.71 \%$ and $11.61 \%$ to $44.11 \%$, respectively. A phthalation degree increase of cellulose was proportional to phthalic anhydride dosage due to its regular macromolecular structure and followed the equation $y_{\mathrm{PDI}}=0.004 x-0.02$. FT-IR and 2D HSQC NMR analyses confirmed the attachment of phthaloyl group. The phthalation reactivity of the three hydroxyls in the isolated cellulose followed the order of C- $6>$ C-2 $>$ C-3, and the more selective phthalation to C-6 position was found in the cellulose component in bagasse. These results provide detailed understanding of the homogenous modification mechanism of lignocellulose.
\end{abstract}

\section{Introduction}

Bagasse, an abundant agricultural lignocellulosic by-product, represents a potentially sustainable biomass resource to create fuels, chemicals, and composites to replace fossil-based products. The bioproducts derived from bagasse have been applied in many industrial fields such as coating, food-packing, and painting $[1,2]$, paving the way to replace the fossil-based products.

However, bagasse presents considerable chemical and physical inertness, such as complex structure, strong hydrogen bonds, and high crystallinity of cellulose, which restricts the dissolution of bagasse in common organic or inorganic solvents. Fortunately, some novel solvents or solvent systems have been reported to dissolve lignocellulosic materials [35]. Among these novel solvents, ionic liquids (ILs) have received much attention due to the recoverability, designability, extremely low vapor pressure, inflammableness, and thermal and chemical stability [6]. The bridge between ILs and biomass has been built from over ten years ago [7], and many homogeneous modifications of lignocellulose have been investigated in ILs [8,9], among which esterification of the available reactive hydroxyls is relatively easily accomplished. However, due to the obstacle to obtain detailed information of esterified lignocellulose, the homogeneous esterification mechanism was little studied.

To obtain more detailed structural information, many efforts have been devoted to establish efficient solvent systems for the complete and nonderivative dissolution of plant cell walls. Ball-milling was reported to benefit the dissolution of lignocellulose for spectroscopic analysis [10]. The combination of ball-milling and efficient solvent systems makes the characterization of lignocellulosic cell walls with 2D HSQC NMR feasible, which could offset the lack of detailed information provided by solid-state ${ }^{13} \mathrm{C}$-NMR commonly 
used in the previous studies [11, 12]. Based on ball-milling, a so-called "gel-state NMR method" was developed with solution-state $2 \mathrm{D}$ NMR $[13,14]$. The assignment of the correlations in 2D HSQC NMR spectra was reported from various cellulose models [15], providing the database of cell wall samples for further investigation.

Considering the complex structure and various linkages among different components of lignocellulose, the homogeneous phthalation of lignocellulose was investigated comparatively with the isolated component under the same conditions to elucidate the mechanism. In the present study, the isolated cellulose and bagasse were comparatively phthalated. The phthalated samples were characterized with FT-IR, ${ }^{1} \mathrm{H}$ NMR, ${ }^{13} \mathrm{C}$ NMR, and 2D HSQC NMR to study the reaction behavior of cellulose fractions in bagasse phthalation. The thermal stability of the phthalated samples was also studied with thermogravimetric analysis (TGA).

\section{Material and Methods}

2.1. Materials. Bagasse was obtained from a local factory (Jiangmen, China). It was dried in sunlight and cut into small pieces. The cut bagasse was ground and screened to prepare 20-40 mesh size particles $(450-900 \mu \mathrm{m})$. The dried ground samples were extracted with toluene-ethanol $(2: 1$, $\mathrm{v} / \mathrm{v}$ ) for $4 \mathrm{~h}$ and then dried in a cabinet oven with air circulation at $50^{\circ} \mathrm{C}$ for $24 \mathrm{~h}$. The extractive-free bagasse was divided into two parts: one was finely ball-milled for $48 \mathrm{~h}$ in a planetary BM4 ball-miller (Grinder, Beijing, China) at $608 \mathrm{rpm}$ for further characterization and modification and the other for the isolation of cellulose. The contents of cellulose, hemicelluloses, and lignin in the extractivefree bagasse were determined as $44.85 \%, 33.13 \%$, and $19.14 \%$, respectively, according to the standard NREL methods [16].

1-Allyl-3-methylimidazium chloride (AmimCl) IL was purchased from ChengJie Chemical Co., Ltd. (Shanghai, China), and used as received. Phthalic anhydride (PA) and other chemicals were of analytical grade and were purchased from Guangzhou Chemical Reagent Factory (Guangdong, China).

2.2. Isolation of Cellulose from Bagasse. Cellulose was isolated from the extractive-free bagasse according to the previous literature [12]. Briefly, the extractive-free bagasse was delignified at $75^{\circ} \mathrm{C}$ for $2 \mathrm{~h}$ with sodium chlorite at $\mathrm{pH} 3.8-4.0$, adjusted by $10 \%$ acetic acid. The solid residues were collected by filtration, washed with distilled water until neutral $\mathrm{pH}$, then washed with ethanol, and dried in a cabinet oven for $16 \mathrm{~h}$ at $50^{\circ} \mathrm{C}$. The solid residues were extracted with $10 \% \mathrm{NaOH}$ at a solid to liquor ratio of $1: 20 \mathrm{~g} / \mathrm{mL}$ for $10 \mathrm{~h}$ at $20^{\circ} \mathrm{C}$. The alkaline extraction procedure was repeated thrice to remove the noncellulosic substances. The solid residues were filtered out, washed thoroughly with distilled water, then washed with ethanol, and dried in an oven with air circulation at $50^{\circ} \mathrm{C}$ for $24 \mathrm{~h}$.

2.3. Homogeneous Phthalation. The isolated cellulose ( $4.8 \mathrm{~g}$ ) was finely ball-milled for $48 \mathrm{~h}$ in a planetary BM4 ball-miller (Grinder, Beijing, China) at $608 \mathrm{rpm}$. Ball-milled cellulose or bagasse $(0.5 \mathrm{~g})$ was dispersed in $10 \mathrm{~g} \mathrm{AmimCl}$ at room temperature with agitation under nitrogen atmosphere for $10 \mathrm{~min}$, and the suspension was stirred at $90^{\circ} \mathrm{C}$ for $4 \mathrm{~h}$ to obtain a clear solution. PA was added portionwise to the solution with the dosage of $10,20,30,40$, and $50 \mathrm{mmol} / \mathrm{g}$, respectively. The mixture was agitated at $90^{\circ} \mathrm{C}$ for $90 \mathrm{~min}$ under $\mathrm{N}_{2}$ atmosphere for phthalation. After the required time, the resulted solution was cooled to room temperature and added into $200 \mathrm{~mL}$ ethanol with agitation. The suspension was further continuously stirred for $12 \mathrm{~h}$ to thoroughly precipitate the phthalated products. The solid residues were filtered out, thoroughly washed with ethanol (four times, total $800 \mathrm{~mL}$ ) to remove unreacted $\mathrm{PA}, \mathrm{AmimCl}$, and byproducts, and freeze-dried for further characterization [17].

2.4. Determination of Phthalation Degree. The substituted hydroxyl contents of phthalated samples were determined based on the equivalent volume of $\mathrm{NaOH}$ and $\mathrm{HCl}$ standard solution by back-titration method [18] according to the following:

$$
\mathrm{SHC}=\frac{c_{\mathrm{NaOH}} \times V_{\mathrm{NaOH}}-c_{\mathrm{HCl}} \times V_{\mathrm{HCl}}}{2} \times \frac{1000}{m},
$$

where SHC ( $\mathrm{mmol} / \mathrm{g})$ is the substituted hydroxyls contents, $m(\mathrm{~g})$ is the dry weight of sample analyzed, $c_{\mathrm{NaOH}}(\mathrm{mol} / \mathrm{L})$ is the molarity of $\mathrm{NaOH}$ standard solution, $V_{\mathrm{NaOH}}(\mathrm{mL})$ is the consumed volume of $\mathrm{NaOH}$ standard solution, $c_{\mathrm{HCl}}(\mathrm{mol} / \mathrm{L})$ is the molarity of $\mathrm{HCl}$ standard solution, and $V_{\mathrm{HCl}}(\mathrm{mL})$ is the consumed volume of $\mathrm{HCl}$ standard solution.

Based on the assumption that cellulose is composed of anhydroglucose (AGU), the theoretical hydroxyl contents of the unmodified cellulose were calculated from its macromolecular structure according to (2), the theoretical hydroxyl contents of phthalated bagasse samples were calculated based on the contents of three main components according to (3), and phthalation degree of cellulose and bagasse was calculated based on (4).

$$
\mathrm{THC}_{\mathrm{C}}=\frac{1000}{162} \times 3,
$$

where $\mathrm{THC}_{\mathrm{C}}$ is the theoretical hydroxyl groups content of unmodified cellulose, $162 \mathrm{~g} / \mathrm{mol}$ is the molar mass of AGU, and 3 is the number of hydroxyl groups on each AGU.

$$
\begin{aligned}
\mathrm{THC}_{\mathrm{B}}= & \mathrm{THC}_{\mathrm{C}} \times 44.85 \%+\mathrm{THC}_{\mathrm{H}} \times 33.13 \%+\mathrm{THC}_{\mathrm{L}} \\
& \times 19.14 \%,
\end{aligned}
$$

where $\mathrm{THC}_{\mathrm{B}}, \mathrm{THC}_{\mathrm{C}}, \mathrm{THC}_{\mathrm{H}}$, and $\mathrm{THC}_{\mathrm{L}}$ are the theoretical hydroxyl groups content of the unmodified bagasse, cellulose, hemicelluloses, and lignin, respectively, and 44.85\%, 33.13\%, and $19.14 \%$ are the contents of cellulose, hemicelluloses, and lignin, respectively, in the extractive-free bagasse. The theoretical hydroxyl contents of the unmodified hemicelluloses and lignin were 15.15 and $5.13 \mathrm{mmol} / \mathrm{g}$ (data not shown).

$$
\mathrm{PD}=\frac{\mathrm{SHC}}{\mathrm{THC}} \times 100 \%,
$$

where PD is the phthalation degree, $\mathrm{SHC}$ is the substituted hydroxyl contents, and THC is the theoretical hydroxyl contents. 
TABLE 1: The substituted hydroxyl contents and phthalation degrees of the phthalated cellulose and bagasse.

\begin{tabular}{|c|c|c|c|c|c|c|c|}
\hline Sample no. & Temp. $\left({ }^{\circ} \mathrm{C}\right)$ & PA dosage $^{\mathrm{a}}(\mathrm{mmol} / \mathrm{g})$ & Solvent & Time $(\mathrm{h})$ & $\mathrm{THC}^{\mathrm{b}}(\mathrm{mmol} / \mathrm{g})$ & $\mathrm{SHC}^{\mathrm{c}}(\mathrm{mmol} / \mathrm{g})$ & $\mathrm{PD}^{\mathrm{d}}(\%)$ \\
\hline $\mathrm{C} 1$ & 90 & 10 & $\mathrm{AmimCl}$ & 1.5 & 18.52 & 2.15 & 11.61 \\
\hline $\mathrm{C} 2$ & 90 & 20 & $\mathrm{AmimCl}$ & 1.5 & 18.52 & 2.61 & 14.09 \\
\hline $\mathrm{C} 3$ & 90 & 30 & $\mathrm{AmimCl}$ & 1.5 & 18.52 & 3.71 & 20.03 \\
\hline $\mathrm{C} 4$ & 90 & 40 & $\mathrm{AmimCl}$ & 1.5 & 18.52 & 5.51 & 29.75 \\
\hline C5 & 90 & 50 & AmimCl & 1.5 & 18.52 & 8.17 & 44.11 \\
\hline S1 & 90 & 10 & AmimCl & 1.5 & 14.31 & 0.81 & 5.66 \\
\hline S2 & 90 & 20 & $\mathrm{AmimCl}$ & 1.5 & 14.31 & 1.47 & 10.27 \\
\hline S3 & 90 & 30 & $\mathrm{AmimCl}$ & 1.5 & 14.31 & 1.94 & 13.56 \\
\hline S4 & 90 & 40 & $\mathrm{AmimCl}$ & 1.5 & 14.31 & 2.92 & 20.41 \\
\hline S5 & 90 & 50 & AmimCl & 1.5 & 14.31 & 3.25 & 22.71 \\
\hline
\end{tabular}

${ }^{\mathrm{a}}$ The ratio of phthalic anhydride ( $\left.\mathrm{mmol}\right)$ to biomass material ( $\mathrm{g}$, bagasse or cellulose).

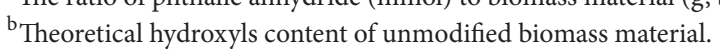

${ }^{\mathrm{c}}$ Substituted hydroxyl contents determined by back titration.

${ }^{\mathrm{d}}$ Phthalation degree.

2.5. Characterization. FT-IR spectra were obtained on FT-IR spectrophotometer (Nicolet 510) using a $\mathrm{KBr}$ disk containing approximately $1 \%$ finely ground samples. Thirty-two scans were taken for each sample with a resolution of $2 \mathrm{~cm}^{-1}$ in transmittance mode in the range of $4000-400 \mathrm{~cm}^{-1}$.

The ${ }^{1} \mathrm{H}$ NMR, ${ }^{13} \mathrm{C}$ NMR, and 2D HSQC NMR spectra were recorded from $40 \mathrm{mg}$ samples in $0.5 \mathrm{~mL} \mathrm{DMSO}-d_{6}$ on a Bruker Advance III $600 \mathrm{MHz}$ spectrometer (Germany). The ${ }^{1} \mathrm{H}$ NMR and ${ }^{13} \mathrm{C}$ NMR spectra were recorded according to the previous literature [19]. For the ${ }^{1} \mathrm{H}$ NMR analysis, the detailed collecting and processing parameters were as follows: number of scans, 16; receiver gain, 61; acquisition time, $2.7263 \mathrm{~s}$; relaxation delay, $1.0 \mathrm{~s}$; pulse width, $11.0 \mathrm{~s}$; spectrometer frequency, $600.17 \mathrm{MHz}$; and spectral width, 12019.2 Hz. For ${ }^{13} \mathrm{C}$ NMR analysis, the detailed collecting and processing parameters were as follows: number of scans, 10000; receiver gain, 187; acquisition time, $0.9088 \mathrm{~s}$; relaxation delay, $2.0 \mathrm{~s}$; pulse width, $12.0 \mathrm{~s}$; spectrometer frequency, 150.91 MHz; and spectral width, $36057.7 \mathrm{~Hz}$. For 2D HSQC analysis, the detailed collecting and processing parameters were listed as follows: number of scans, 32; receiver gain, 187; relaxation delay, $1.5 \mathrm{~s}$; pulse width, $11.0 \mathrm{~s}$; acquisition time, $0.1420 \mathrm{~s}$; spectra frequency, $600.17 / 150.91 \mathrm{~Hz}$; and spectra width, 7211.5/24875.6 Hz.

The thermal stability of cellulose samples was studied using thermogravimetric analysis (TGA) on a thermal analyzer (SDT Q600, TA Instrument). The apparatus was continually flushed with nitrogen. The sample weighed between 8 and $10 \mathrm{mg}$, and the scans were run from $50^{\circ} \mathrm{C}$ to $500^{\circ} \mathrm{C}$ at a heating rate of $10^{\circ} \mathrm{C} / \mathrm{min}$.

\section{Results and Discussion}

3.1. Homogeneous Phthalation of Cellulose in Bagasse. It is well known that the complex inhomogeneous structure of bagasse is formed by three main components including cellulose, hemicelluloses, and lignin. Actually, the homogeneous phthalation of bagasse is the phthalation of the abundant reactive hydroxyl groups in the three main components. Therefore, in order to elucidate the mechanism of homogeneous phthalation, the isolated cellulose was comparatively phthalated under the same conditions as bagasse to estimate the detailed reaction behavior of cellulose in the phthalation of bagasse mixture in AmimCl, as listed in Table 1.

Theoretically, each AGU contains three hydroxyl groups, and the free hydroxyl group content of the isolated cellulose is $18.52 \mathrm{mmol} / \mathrm{g}$. After phthalation in AmimCl, some of the hydroxyl groups were substituted, as shown in Table 1. With the increment of PA dosage from 10 to 20, 30, 40, and $50 \mathrm{mmol} / \mathrm{g}$, the substituted hydroxyl contents in the phthalated cellulose estimated from back titration increased from 2.15 to $2.61,3.71,5.51$, and $8.17 \mathrm{mmol} / \mathrm{g}$, respectively, and the free hydroxyl content decreased from 16.37 to $15.91,14.81$, 13.01 , and $10.35 \mathrm{mmol} / \mathrm{g}$, respectively. Correspondingly, the phthalation degree increased from $11.61 \%$ to $14.09 \%, 20.03 \%$, $29.75 \%$, and $44.11 \%$, respectively. These results confirmed the occurrence of phthalation of the isolated cellulose under the selected conditions. Similarly, the substituted hydroxyl contents in bagasse increased from 0.81 to $1.47,1.94,2.92$, and $3.25 \mathrm{mmol} / \mathrm{g}$, respectively, with the increment of PA dosage from 10 to $20,30,40$, and $50 \mathrm{mmol} / \mathrm{g}$. The free hydroxyl group content in unmodified bagasse, that is, the theoretical hydroxyls content, was $14.31 \mathrm{mmol} / \mathrm{g}$ estimated from the three main components based on their contents. The free hydroxyl content correspondingly decreased from 13.50 to $12.84,12.37$, 11.39 , and $11.06 \mathrm{mmol} / \mathrm{g}$, respectively, and the phthalation degree increased from $5.66 \%$ to $10.27 \%, 13.56 \%, 20.41 \%$, and $22.71 \%$, respectively. Comparatively, the phthalation degree of bagasse was lower than that of the isolated cellulose, indicating the higher phthalation ability of the isolated cellulose. Comparatively, the decreased phthalation degree of bagasse was due to the different contents and reactivity of hydroxyls in the three main components compared with 


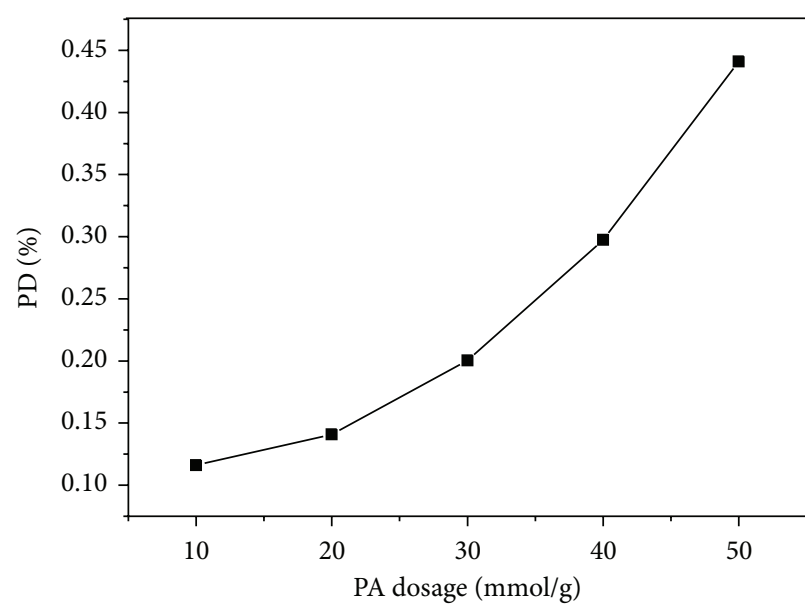

(a)

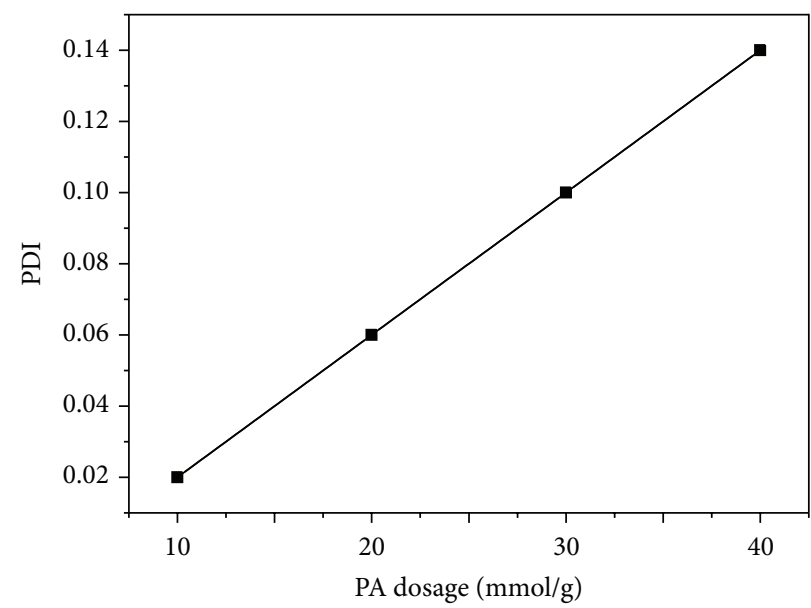

(b)

FIGURE 1: Dependence of phthalation degree ((PD), (a)) and phthalation degree increase ((PDI), (b)) on phthalic anhydride dosage.

the isolated ones. In addition, a very interesting phenomenon was found for the phthalation degree increase (PDI): PDI of cellulose was proportional to phthalic anhydride dosage, which followed the equation of $y_{\mathrm{PDI}}=0.004 x-0.02$, as shown in Figure 1. This regular relation was probably due to the regular macromolecular structure of cellulose. The detailed differences of the hydroxyl reactivity in different positions need to be further clarified.

3.2. FT-IR Analysis. FT-IR spectra of unmodified cellulose $(\mathrm{C} 0$, spectrum a) and phthalated cellulose samples $(\mathrm{C} 1$, spectrum b; C3, spectrum c; C4, spectrum d) are illustrated in Figure 2. The bands were assigned based on the reported literatures $[20,21]$. Compared with unmodified cellulose, the noticeable bands at $1716,1602,1327$, and $747 \mathrm{~cm}^{-1}$ in the phthalated samples correspond to carbonyl group in esters, aromatic ring vibration, $\mathrm{C}-\mathrm{O}$ stretching in carboxyl, and outof-plane $\mathrm{C}-\mathrm{H}$ bending of benzene, respectively. The presence of these bands indicated the successful phthalation of cellulose. It should be noted that the intensities of these bands increased with the increment of PA dosage, corresponding to the increased substituted hydroxyl contents and phthalation degree in Table 1.

3.3. NMR Analysis. To further elucidate the detailed behavior of hydroxyls in different positions in AGU during phthalation, the unmodified (C0) and phthalated cellulose (C5) as well as phthalated bagasse (S5) were further characterized with $1 \mathrm{D}\left({ }^{1} \mathrm{H}\right.$ and $\left.{ }^{13} \mathrm{C}\right)$ and $2 \mathrm{D}$ (HSQC) NMR technology in DMSO- $d_{6}$, as illustrated in Figures 3 and 4.

${ }^{1} \mathrm{H}$ NMR spectra of unmodified cellulose ( $\mathrm{C} 0$, spectrum a), phthalated cellulose ( $\mathrm{C}$, spectrum b), and phthalated bagasse ( 55 , spectrum c) are present in Figure 3. As can be seen, the relevant signals are present in two regions, namely, the AGU protons region (4.50-3.00 ppm) and the phthaloyl protons region (8.00-7.00 $\mathrm{ppm}$ ). Compared with unmodified



FIGURE 2: FT-IR spectra of unmodified cellulose (C0, spectrum a) and modified cellulose with phthalic anhydride dosage at $10(\mathrm{Cl}$, spectrum b), 30 (C3, spectrum c), and 40 (C4, spectrum d) mmol/g.

cellulose, the presence of peaks at $7.87(\mathrm{H}-10), 7.76(\mathrm{H}-13)$, $7.69(\mathrm{H}-11)$, and $7.60(\mathrm{H}-12) \mathrm{ppm}$ for phthaloyl protons in the phthalated cellulose and phthalated bagasse confirmed the phthalation of cellulose and bagasse.

The ${ }^{13} \mathrm{C}$ NMR spectra of unmodified cellulose (C0, spectrum d), phthalated cellulose (C5, spectrum e), and phthalated bagasse ( 55 , spectrum $\mathrm{f}$ ) exhibit main signals in Figure 3; the carbon skeletons of AGU at 102.83 (C1), 80.43 (C-4), 75.27 (C-5), 75.27 (C-3), 70.38 (C-2), and $60.74(\mathrm{C}-6) \mathrm{ppm}$ were well resolved. In the region 180 $120 \mathrm{ppm}$, the cross-peaks at 168.85 (C-7), 167.57 (C-14), 134.95 (C-8), 133.34 (C-9), 132.20 (C-13), 131.71 (C-10), 130.86 (C12 ), and 129.09 (C-11) ppm were assigned to carbons of the phthaloyl groups, respectively, in phthalated cellulose and phthalated bagasse, confirming the attachment of phthaloyl groups onto cellulose and bagasse. This result was consistent 


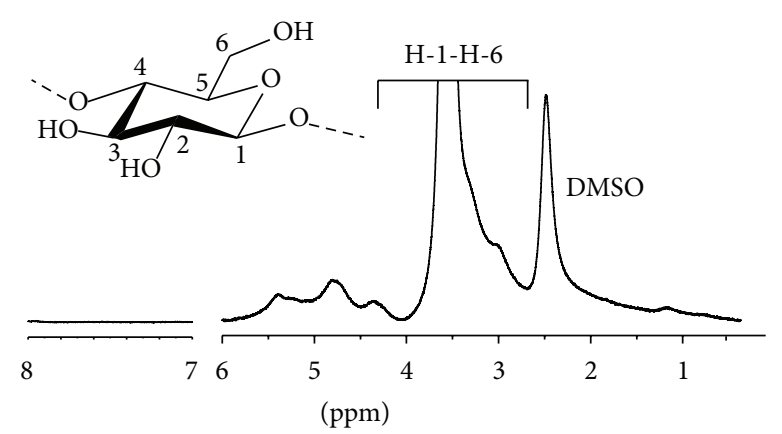

(a)

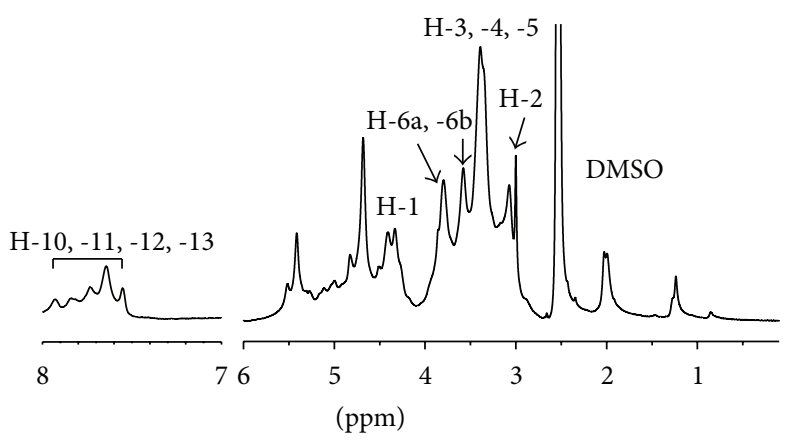

(c)

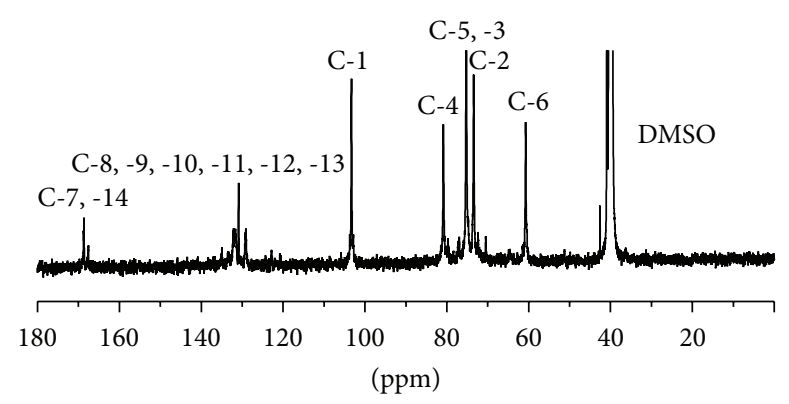

(e)

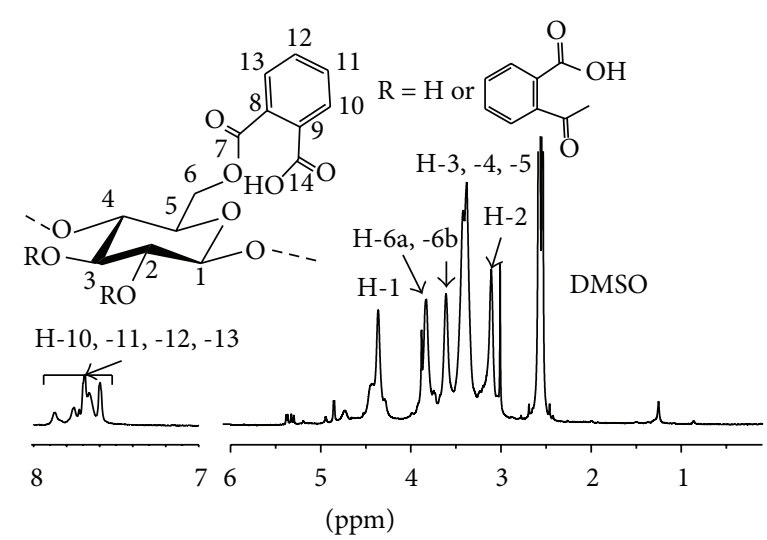

(b)

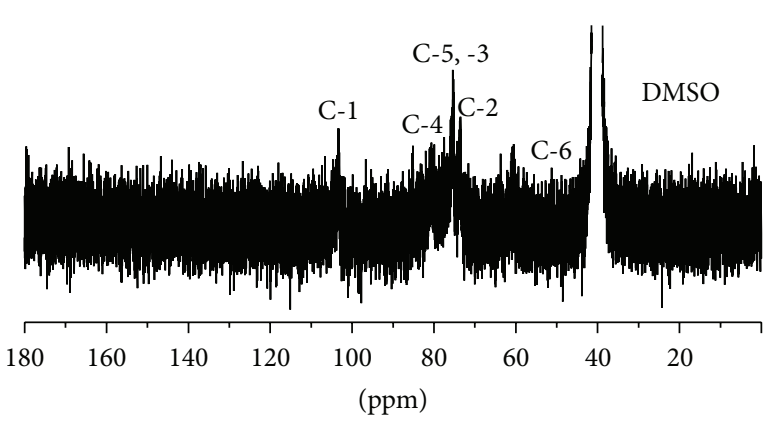

(d)

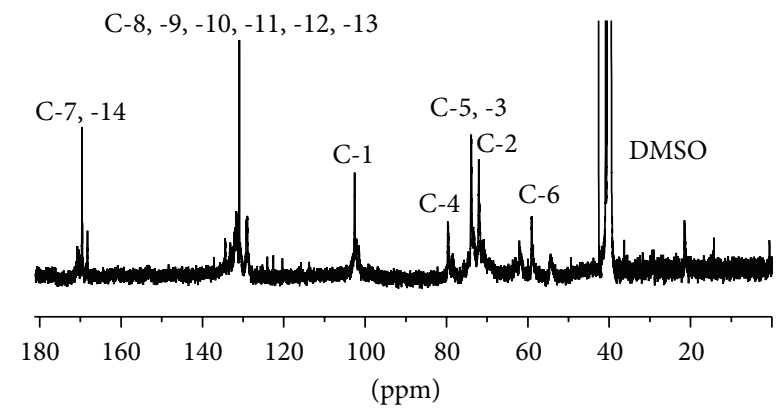

(f)

Figure 3: The ${ }^{1} \mathrm{H}\left((\mathrm{a}),(\mathrm{b})\right.$, and (c)) and ${ }^{13} \mathrm{C}((\mathrm{d}),(\mathrm{e})$, and (f)) NMR spectra of unmodified cellulose (C0), phthalated cellulose (C5), and phthalated bagasse (S5).

with the previously reported esterification of wood with cyclic anhydride (succinic anhydride, maleic anhydride, and phthalic anhydride) as main monoesterification below $100^{\circ} \mathrm{C}$ [22]. However, the reactivity of hydroxyls from phthalated cellulose and phthalated bagasse during homogeneous phthalation could not be revealed from the ${ }^{1} \mathrm{H}$ NMR and ${ }^{13} \mathrm{C}$ NMR analyses. Therefore, further investigation with 2D HSQC was necessary.

The HSQC spectra of unmodified cellulose (C0, spectrum a) and phthalated cellulose (C5, spectra b and d), as well as the carbohydrate regions of phthalated bagasse (S5, spectrum c), are shown in Figure 4. The primary polysaccharide correlation peaks in HSQC spectra appeared in the range of 110-55 ppm $\left({ }^{13} \mathrm{C}\right)$ and $6.0-2.5 \mathrm{ppm}\left({ }^{1} \mathrm{H}\right)$. These correlations were assigned based on cellulose models reported previously [15], as listed in Table 2. The primary peaks of cellulose internal units (C-I) in this region were clearly observed from the unmodified cellulose at 73.49/3.06 $\left[\mathrm{C}-\mathrm{I}_{2}\left(\mathrm{C}_{2} / \mathrm{H}_{2}\right)\right], 75.33 / 3.36$ $\left[\mathrm{C}-\mathrm{I}_{3}\left(\mathrm{C}_{3} / \mathrm{H}_{3}\right)\right], 80.85 / 3.33\left[\mathrm{C}-\mathrm{I}_{4}\left(\mathrm{C}_{4} / \mathrm{H}_{4}\right)\right], 77.14 / 3.18[\mathrm{C}-$ $\left.\mathrm{I}_{5}\left(\mathrm{C}_{5} / \mathrm{H}_{5}\right)\right]$, and $103.44 / 4.33\left[\mathrm{C}-\mathrm{I}_{1}\left(\mathrm{C}_{1} / \mathrm{H}_{1}\right)\right] \mathrm{ppm}$; the two internal C- $\mathrm{I}_{6}\left(\mathrm{C}_{6} / \mathrm{H}_{6}\right)$ peaks were also distinctively located at $60.77 / 3.79$ and $60.77 / 3.58 \mathrm{ppm}$.

The end-group correlations were well resolved in the unmodified cellulose; however, some peaks were superimposed with other peaks. The correlations for nonreducing-end $\mathrm{C}-\mathrm{NR}_{6}\left(\mathrm{C}_{6} / \mathrm{H}_{6}\right)$ were well separated from the internal $\mathrm{C}-\mathrm{I}_{6}\left(\mathrm{C}_{6} / \mathrm{H}_{6}\right)$ and appeared at 61.50/3.69 and $61.50 / 3.39 \mathrm{ppm}$. That for $\mathrm{C}-\mathrm{NR}_{4}\left(\mathrm{C}_{4} / \mathrm{H}_{4}\right)$ was clearly present 


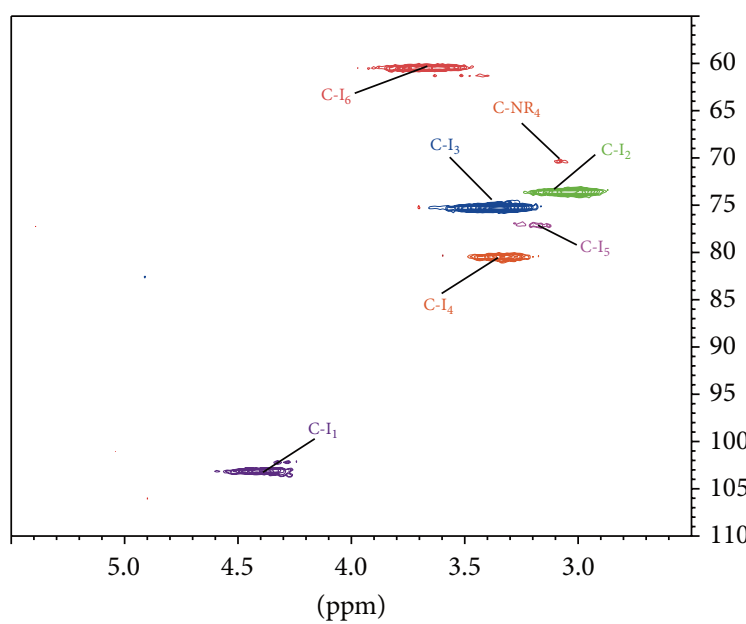

(a)

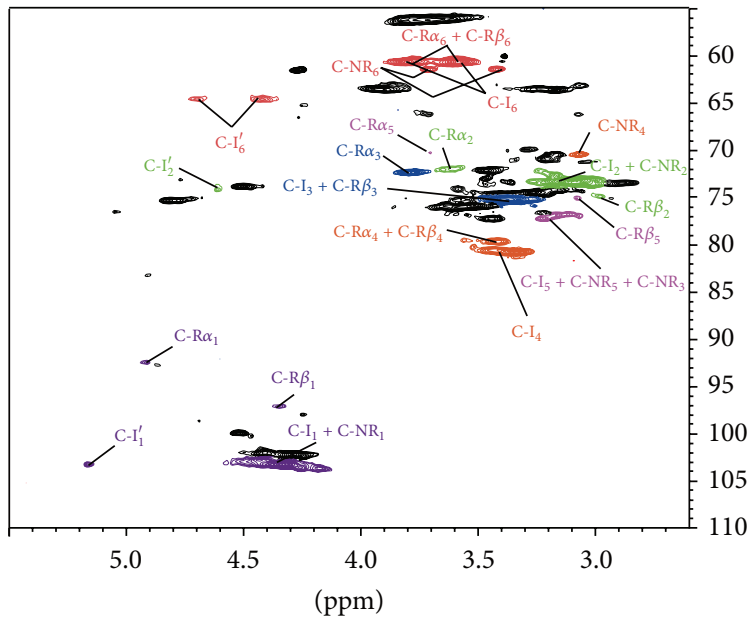

(c)

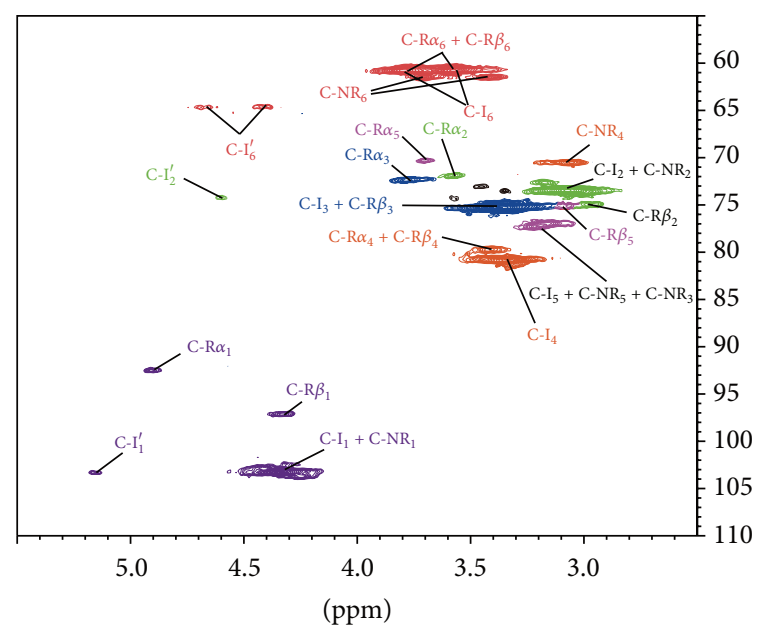

(b)
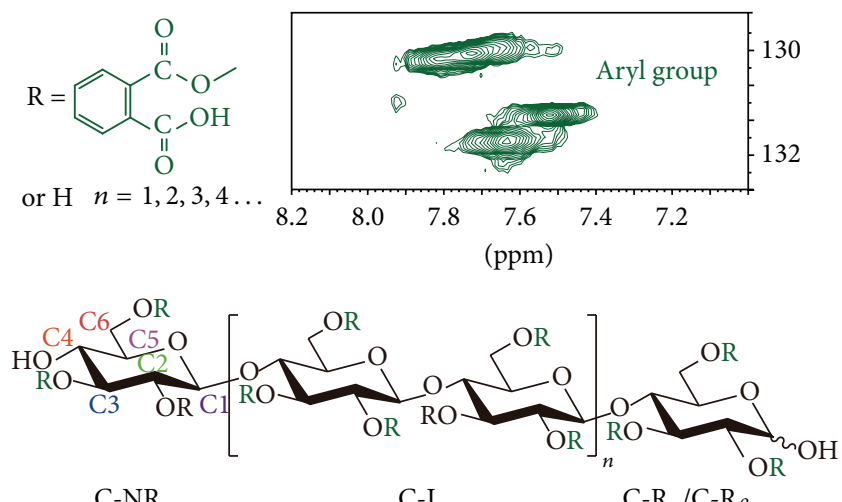

(d)

FIGURE 4: 2D HSQC NMR spectra of unmodified cellulose (C0, spectrum a), phthalated cellulose (C5, spectra b and d), and phthalated bagasse ( $\mathrm{S} 5$, spectrum $\mathrm{c}$ ).

TABLE 2: Primary NMR correlations in DMSO- $d_{6}$ for cellulose modified with phthalic anhydride.

\begin{tabular}{|c|c|c|c|c|c|c|c|c|}
\hline \multicolumn{2}{|c|}{ Glycosyl residue } & \multicolumn{7}{|c|}{${ }^{1} \mathrm{H} \&{ }^{13} \mathrm{C}$ chemical shifts (ppm) } \\
\hline Giycosyites & & 1 & 2 & 3 & 4 & 5 & $6 a$ & $6 b$ \\
\hline \multirow{2}{*}{ Cellulose (internal) } & ${ }^{1} \mathrm{H}$ & 4.31 & 3.05 & 3.36 & 3.30 & 3.16 & 3.56 & 3.77 \\
\hline & ${ }^{13} \mathrm{C}$ & 103.26 & 73.56 & 75.24 & 80.97 & 77.18 & 60.74 & 60.74 \\
\hline \multirow{2}{*}{ Cellulose (NR) } & ${ }^{1} \mathrm{H}$ & 4.23 & 2.98 & 3.15 & 3.05 & 3.16 & 3.39 & 3.69 \\
\hline & ${ }^{13} \mathrm{C}$ & 103.65 & 73.77 & 77.07 & 70.54 & 77.18 & 61.50 & 61.50 \\
\hline \multirow{2}{*}{ Cellulose $(\mathrm{R} \alpha)$} & ${ }^{1} \mathrm{H}$ & 4.89 & 3.16 & 3.69 & 3.31 & 3.68 & 3.56 & 3.72 \\
\hline & ${ }^{13} \mathrm{C}$ & 92.44 & 72.68 & 72.11 & 81.36 & 70.25 & 60.80 & 60.80 \\
\hline \multirow{2}{*}{ Cellulose $(\mathrm{R} \beta)$} & ${ }^{1} \mathrm{H}$ & 5.14 & 2.93 & 3.25 & 3.31 & 3.06 & 3.56 & 3.72 \\
\hline & ${ }^{13} \mathrm{C}$ & 103.31 & 74.93 & 75.24 & 81.36 & 75.13 & 60.80 & 60.80 \\
\hline
\end{tabular}

at 70.54/3.05 ppm, while the correlations at 73.77/2.98 ppm for $\mathrm{C}-\mathrm{NR}_{2}\left(\mathrm{C}_{2} / \mathrm{H}_{2}\right)$ were located very close to the internal C$\mathrm{I}_{2}\left(\mathrm{C}_{2} / \mathrm{H}_{2}\right)$. Those for C-NR $\left(\mathrm{C}_{3} / \mathrm{H}_{3}\right)$ and C-NR $\left(\mathrm{C}_{5} / \mathrm{H}_{5}\right)$ had the coincident chemical shifts and overlapped with the internal C- $\mathrm{I}_{5}\left(\mathrm{C}_{5} / \mathrm{H}_{5}\right)$ correlation at $77.07 / 3.18 \mathrm{ppm}$. The anomeric peak from non-reducing-end $\mathrm{C}-\mathrm{NR}_{1}$ appeared at $103.65 / 4.23 \mathrm{ppm}\left(\mathrm{C}_{1} / \mathrm{H}_{1}\right)$. The $\alpha$ - and $\beta$-anomer from reducing-end correlations of cellulose were clearly separated from those of the internal units. The $\mathrm{C}_{1} / \mathrm{H}_{1}$ correlation from the reducing-terminal-end of $\alpha$-D-glucuronic polysaccharide $\left(\alpha\right.$-D-Glcp) (C-R $\left.\alpha_{1}\right)$ was at $92.44 / 4.89 \mathrm{ppm}$, while the analogous $\beta$-D-Glcp $\left(\mathrm{C}-\mathrm{R} \beta_{1}\right)$ correlation was at 103.31/5.14 ppm. 

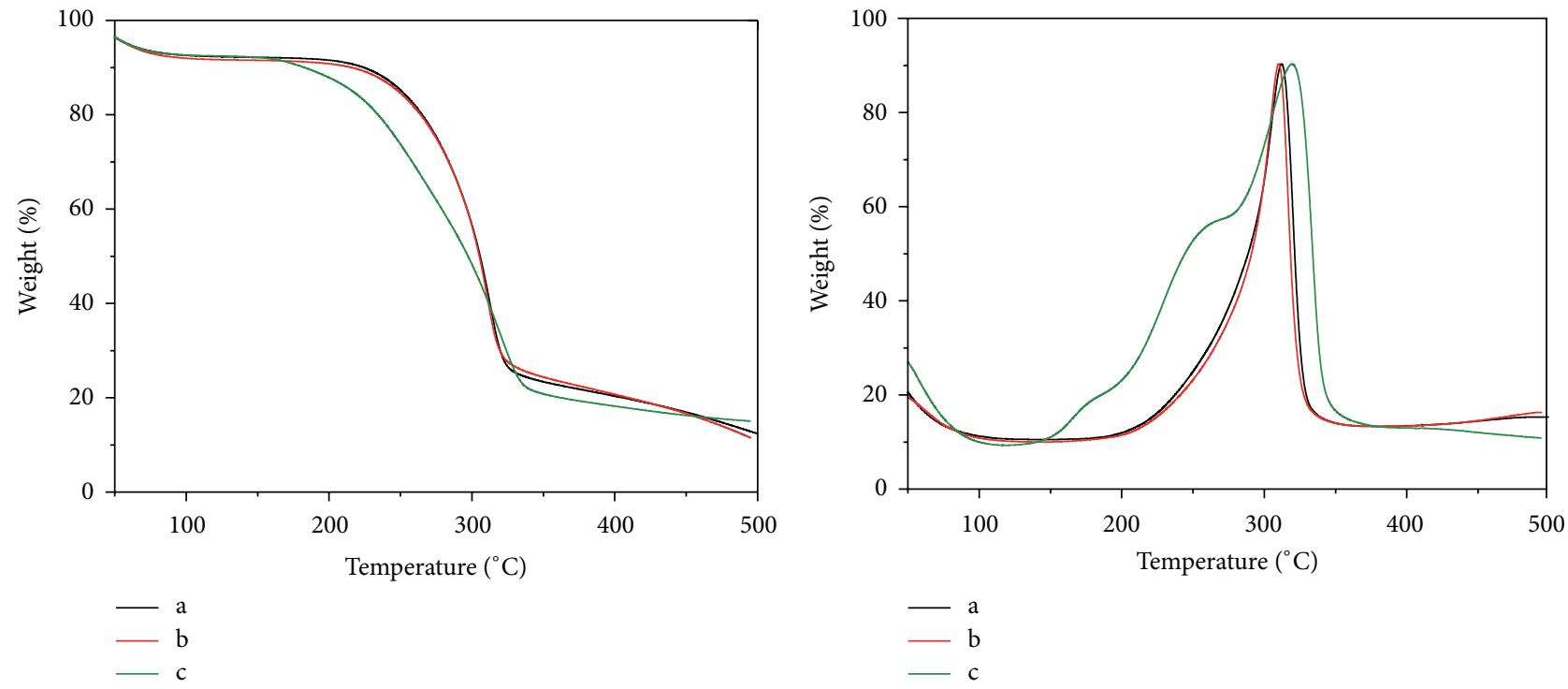

Figure 5: The TG/DTG curves of unmodified cellulose (C0, curve a) and phthalated cellulose samples (C1, curve b; C5, curve c).

Despite the conformational complexity, primary peaks were evidently assigned from $\alpha$-D-Glcp: 72.68/3.16 [C-R $\alpha_{2}$ $\left.\left(\mathrm{C}_{2} / \mathrm{H}_{2}\right)\right], 72.11 / 3.69\left[\mathrm{C}-\mathrm{R} \alpha_{3}\left(\mathrm{C}_{3} / \mathrm{H}_{3}\right)\right]$, and 70.25/3.68 [C$\left.\mathrm{R} \alpha_{5}\left(\mathrm{C}_{5} / \mathrm{H}_{5}\right)\right]$ ppm. Similarly, C-R $\beta_{2}\left(\mathrm{C}_{2} / \mathrm{H}_{2}\right)$ and $\mathrm{C}-\mathrm{R} \beta_{5}$ $\left(\mathrm{C}_{5} / \mathrm{H}_{5}\right)$ were well resolved at 74.93/2.93 and 75.13/3.06 ppm, respectively. However, $\mathrm{C}-\mathrm{R} \beta_{3}\left(\mathrm{C}_{3} / \mathrm{H}_{3}\right)$ was coincident with $\mathrm{C}$ $\mathrm{I}_{3}$ at 75.24/3.25 ppm. In addition, $\mathrm{C}-\mathrm{R} \alpha_{4}\left(\mathrm{C}_{4} / \mathrm{H}_{4}\right)$ and $\mathrm{C}-\mathrm{R} \beta_{4}$ $\left(\mathrm{C}_{4} / \mathrm{H}_{4}\right)$ were coincident at $81.36 / 3.31 \mathrm{ppm}$; C-R $\alpha_{6}\left(\mathrm{C}_{6} / \mathrm{H}_{6}\right)$ and $\mathrm{C}-\mathrm{R} \beta_{6}\left(\mathrm{C}_{6} / \mathrm{H}_{6}\right)$ also were close together at $60.80 / 3.72$ and $60.80 / 3.56 \mathrm{ppm}$ and were buried between the internal C-I peaks. These results indicated that ball-milling treatment led to the severe degradation of cellulosic macromolecules.

Compared with those in the unmodified cellulose, the reducing-end and non-reducing-end peaks, which resulted from low-molecular fractions, were significantly improved in the phthalated cellulose and the phthalated bagasse, indicating the degradation of cellulose macromolecules in IL AmimCl during dissolution and modification. This result corresponded to the FT-IR analysis, and similar degradation was also reported in the previous publications $[23,24]$. The primary internal cellulose peaks were clearly observed in the phthalated cellulose (C5) and bagasse (S5) at 73.54/3.07 [C- $\left.\mathrm{I}_{2}\left(\mathrm{C}_{2} / \mathrm{H}_{2}\right)\right], 75.11 / 3.36\left[\mathrm{C}-\mathrm{I}_{3}\left(\mathrm{C}_{3} / \mathrm{H}_{3}\right)\right], 80.74 / 3.37\left[\mathrm{C}-\mathrm{I}_{4}\right.$ $\left.\left(\mathrm{C}_{4} / \mathrm{H}_{4}\right)\right], 77.00 / 3.45\left[\mathrm{C}-\mathrm{I}_{5}\left(\mathrm{C}_{5} / \mathrm{H}_{5}\right)\right]$, and 103.23/4.34 [C-I $\left(\mathrm{C}_{1} / \mathrm{H}_{1}\right)$ ] ppm; the two internal C- $\mathrm{I}_{6}\left(\mathrm{C}_{6} / \mathrm{H}_{6}\right)$ peaks were also distinctively located at $60.66 / 3.79$ and $60.52 / 3.60 \mathrm{ppm}$.

The presence of the correlations from aryl groups in the phthalated cellulose confirmed the attachment of phthaloyl group onto cellulose. More importantly, two peaks from substituted $\mathrm{C}_{6}$ in phthalated internal units $\left(\mathrm{C}-\mathrm{I}^{\prime}\right) \quad\left[\mathrm{C}-\mathrm{I}_{6}^{\prime}\right.$ $\left.\left(\mathrm{C}_{6} / \mathrm{H}_{6}\right)\right]$ appeared at $64.70 / 3.79$ and $64.70 / 4.42 \mathrm{ppm}$, and the peak from substituted $\mathrm{C}_{2}$ in internal unit $\left[\mathrm{C}-\mathrm{I}_{2}^{\prime}\left(\mathrm{C}_{2} / \mathrm{H}_{2}\right)\right]$ was located at $74.21 / 4.60 \mathrm{ppm}$, confirming the successful phthalation of cellulose at C- 6 and C-2 positions. However, the substituted $\mathrm{C}_{3}$ was almost not detected, which suggested that most of phthaloyl group was attached onto C-6 and C-2 positions. The relative percentage of phthalation on different positions could be evaluated upon the integral area of the characteristic substituted correlations. The results indicated that $24.1 \%$ and $75.9 \%$ of phthaloyl group were attached to $\mathrm{C}_{2}$ and $\mathrm{C}_{6}$ positions, respectively. The relative percentage of phthalation at C-6, C-2, and C-3 positions of cellulose in phthalated bagasse S5 was $94.74 \%, 5.26 \%$, and 0 , respectively. These results indicated that the reaction behavior of cellulose in bagasse was similar to the isolated cellulose and the phthalation was more selective to C-6 position in bagasse than that in the isolated cellulose. Obviously, the phthalation degree of the three hydroxyls in AGU followed the order of C-6 > C-2 > C-3. This order was consistent with the propionylation and butyrylation in $\mathrm{AmimCl}$ [25]. On the other hand, the phthalation degree of the hydroxyls on each position was easily calculated based on the integral area of the characteristic substituted and unsubstituted correlations. The results showed that the phthalation degree in the isolated cellulose was $6.30 \%, 2.01 \%$, and 0 , respectively, while that in bagasse was $15.15 \%, 2.63 \%$, and 0 , respectively. These results were consistent with the abovementioned phthalation order of three hydroxyls. The relatively more selective phthalation for the hydroxyl to C-6 position of cellulose component in bagasse than the isolated cellulose was primarily due to the differences of the phthalation reactivity of more complicated hydroxyls in bagasse.

3.4. Thermal Analysis. The thermal behavior of unmodified cellulose and phthalated cellulose was studied by TGA in $\mathrm{N}_{2}$ atmosphere. Figure 5 illustrates the TGA and DTG curves of the unmodified cellulose ( $\mathrm{C} 0$, curve a) and phthalated cellulose ( $\mathrm{C} 1$, curve b; $\mathrm{C} 5$, curve c). The decrease below $100^{\circ} \mathrm{C}$ was due to loss of moisture. The initial decomposition temperature of samples $\mathrm{C} 0, \mathrm{C} 1$, and $\mathrm{C} 5$ was $251^{\circ} \mathrm{C}, 245^{\circ} \mathrm{C}$, and $213^{\circ} \mathrm{C}$, respectively. At $50 \%$ weight loss, the decomposition temperature occurred at $304^{\circ} \mathrm{C}, 305^{\circ} \mathrm{C}$, and $297^{\circ} \mathrm{C}$ for samples 
$\mathrm{C} 0, \mathrm{Cl}$, and $\mathrm{C} 5$, respectively. The DTG curves suggested that the modified cellulose had higher thermal degradation rate than the unmodified one. These data indicated that the decreased thermal stability of phthalated cellulose is consistent with the results reported previously [26]. Besides, the initial and midpoint decomposition temperatures of sample C5 were both lower than those of sample $\mathrm{Cl}$, indicating that high phthalation degree tended to weaken thermal stability of modified cellulose.

\section{Conclusions}

The phthalation degree of bagasse and the isolated cellulose ranged from $5.66 \%$ to $22.71 \%$ and from $11.61 \%$ to $44.11 \%$, respectively. The phthalation degree increase of cellulose was proportional to phthalic anhydride dosage, which followed the equation of $y_{\mathrm{PDI}}=0.004 x-0.02$ under the selected conditions. The reactivity of the three hydroxyls in cellulose followed the order of C-6 > C-2 > C-3, and more selective phthalation to C-6 positions of cellulose component was found in bagasse than in the isolated cellulose. These results provide a detailed understanding of the homogenous modification mechanism of lignocellulose.

\section{Competing Interests}

The authors declare that they have no competing interests.

\section{Acknowledgments}

This work was financially supported by the National Natural Science Foundation of China (31170550 and 31170555), the Fundamental Research Funds for the Central Universities (2014ZG0046), and the National Program for Support of TopNotch Young Professionals.

\section{References}

[1] C. T. Duan, N. Zhao, X. L. Yu, X. Y. Zhang, and J. Xu, "Chemically modified kapok fiber for fast adsorption of $\mathrm{Pb}^{2+}, \mathrm{Cd}^{2+}$, $\mathrm{Cu}^{2+}$ from aqueous solution," Cellulose, vol. 20, no. 2, pp. 849$-860,2013$.

[2] K. Y. Foo, L. K. Lee, and B. H. Hameed, "Preparation of activated carbon from sugarcane bagasse by microwave assisted activation for the remediation of semi-aerobic landfill leachate," Bioresource Technology, vol. 134, pp. 166-172, 2013.

[3] F. C. Lu and J. Ralph, "Non-degradative dissolution and acetylation of ball-milled plant cell walls: high-resolution solutionstate NMR," Plant Journal, vol. 35, no. 4, pp. 535-544, 2003.

[4] M. Fasching, P. Schröder, R. P. Wollboldt, H. K. Weber, and H. Sixta, "A new and facile method for isolation of lignin from wood based on complete wood dissolution," Holzforschung, vol. 62, no. 1, pp. 15-23, 2008.

[5] T. Q. Yuan, J. He, F. Xu, and R. C. Sun, "A new vision in the research of biomass resources: complete-lignocellulosedissolution system," Progress in Chemistry, vol. 22, no. 2-3, pp. 472-481, 2010.

[6] S. D. Zhu, Y. X. Wu, Q. M. Chen et al., "Dissolution of cellulose with ionic liquids and its application: a mini-review," Green Chemistry, vol. 8, no. 4, pp. 325-327, 2006.
[7] R. P. Swatloski, S. K. Spear, J. D. Holbrey, and R. D. Rogers, "Dissolution of cellose with ionic liquids," Journal of the American Chemical Society, vol. 124, no. 18, pp. 4974-4975, 2002.

[8] E. Rude and M.-P. G. Laborie, "Carbon-13 cross-polarization magic-angle-spinning nuclear magnetic resonance investigation of the interactions between maleic anhydride grafted polypropylene and wood polymers," Applied Spectroscopy, vol. 62, no. 5, pp. 563-568, 2008.

[9] J. C. P. De Melo, E. C. Da Silva Filho, S. A. A. Santana, and C. Airoldi, "Maleic anhydride incorporated onto cellulose and thermodynamics of cation-exchange process at the solid/liquid interface," Colloids and Surfaces A: Physicochemical and Engineering Aspects, vol. 346, no. 1-3, pp. 138-145, 2009.

[10] C. Qu, T. Kishimoto, M. Kishino, M. Hamada, and N. Nakajima, "Heteronuclear single-quantum coherence nuclear magnetic resonance (HSQC NMR) characterization of acetylated fir (Abies sachallnensis MAST) wood regenerated from ionic liquid," Journal of Agricultural and Food Chemistry, vol. 59, no. 10, pp. 5382-5389, 2011.

[11] X.-W. Peng, J.-L. Ren, and R.-C. Sun, "Homogeneous esterification of xylan-rich hemicelluloses with maleic anhydride in ionic liquid," Biomacromolecules, vol. 11, no. 12, pp. 3519-3524, 2010.

[12] C.-F. Liu, R.-C. Sun, M.-H. Qin et al., "Chemical modification of ultrasound-pretreated sugarcane bagasse with maleic anhydride," Industrial Crops and Products, vol. 26, no. 2, pp. 212-219, 2007.

[13] H. Kim, J. Ralph, and T. Akiyama, "Solution-state 2D NMR of ball-milled plant cell wall gels in DMSO- $\mathrm{d}_{6}$," BioEnergy Research, vol. 1, no. 1, pp. 56-66, 2008.

[14] H. Kim and J. Ralph, "Solution-state 2D NMR of ball-milled plant cell wall gels in DMSO- $d_{6} /$ pyridine- $d_{5}$," Organic and Biomolecular Chemistry, vol. 8, no. 3, pp. 576-591, 2010.

[15] H. Kim and J. Ralph, "A gel-state 2D-NMR method for plant cell wall profiling and analysis: a model study with the amorphous cellulose and xylan from ball-milled cotton linters," RSC Advances, vol. 4, no. 15, pp. 7549-7560, 2014.

[16] A. Sluiter, B. Hames, R. Ruiz et al., "Laboratory analytical procedure (LAP): determination of structural carbohydrates and lignin in biomass," Tech. Rep. NREL/TP-510-42618, National Renewable Energy Laboratory, Golden, Colo, USA, 2008.

[17] M. J. Chen and Q. S. Shi, “Transforming sugarcane bagasse into bioplastics via homogeneous modification with phthalic anhydride in ionic liquid," ACS Sustainable Chemistry \& Engineering, vol. 3, no. 10, pp. 2510-2515, 2015.

[18] C. F. Liu, A. P. Zhang, W. Y. Li, F. X. Yue, and R. C. Sun, "Succinoylation of cellulose catalyzed with iodine in ionic liquid," Industrial Crops and Products, vol. 31, no. 2, pp. 363-369, 2010.

[19] C.-Y. Chen, M.-J. Chen, X.-Q. Zhang, C.-F. Liu, and R.-C. Sun, "Per-O-acetylation of cellulose in dimethyl sulfoxide with catalyzed transesterification," Journal of Agricultural and Food Chemistry, vol. 62, no. 15, pp. 3446-3452, 2014.

[20] M. J. Chen, C. Y. Chen, C. F. Liu, and R. C. Sun, "Homogeneous modification of sugarcane bagasse with maleic anhydride in 1-butyl-3-methylimidazolium chloride without any catalysts," Industrial Crops and Products, vol. 46, pp. 380-385, 2013.

[21] J. Wu, H. Zhang, J. Zhang, and J.-S. He, "Homogeneous acetylation and regioselectivity of cellulose in a new ionic liquid," Chemical Journal of Chinese Universities, vol. 27, no. 3, pp. 592594, 2006. 
[22] H. Matsuda, "Preparation and utilization of esterified woods bearing carboxyl groups," Wood Science and Technology, vol. 21, no. 1, pp. 75-88, 1987.

[23] C. F. Liu, R. C. Sun, A. P. Zhang et al., "Homogeneous modification of sugarcane bagasse cellulose with succinic anhydride using a ionic liquid as reaction medium," Carbohydrate Research, vol. 342, no. 7, pp. 919-926, 2007.

[24] C. F. Liu, R. C. Sun, A. P. Zhang, and J. L. Ren, "Preparation of sugarcane bagasse cellulosic phthalate using an ionic liquid as reaction medium," Carbohydrate Polymers, vol. 68, no. 1, pp. 17-25, 2007.

[25] Y. Luan, J. Zhang, M. Zhan, J. Wu, J. Zhang, and J. He, "Highly efficient propionylation and butyralation of cellulose in an ionic liquid catalyzed by 4-dimethylminopyridine," Carbohydrate Polymers, vol. 92, no. 1, pp. 307-311, 2013.

[26] C.-F. Liu, R.-C. Sun, A.-P. Zhang, M.-H. Qin, J.-L. Ren, and X.-A. Wang, "Preparation and characterization of phthalated cellulose derivatives in room-temperature ionic liquid without catalysts," Journal of Agricultural and Food Chemistry, vol. 55, no. 6, pp. 2399-2406, 2007. 

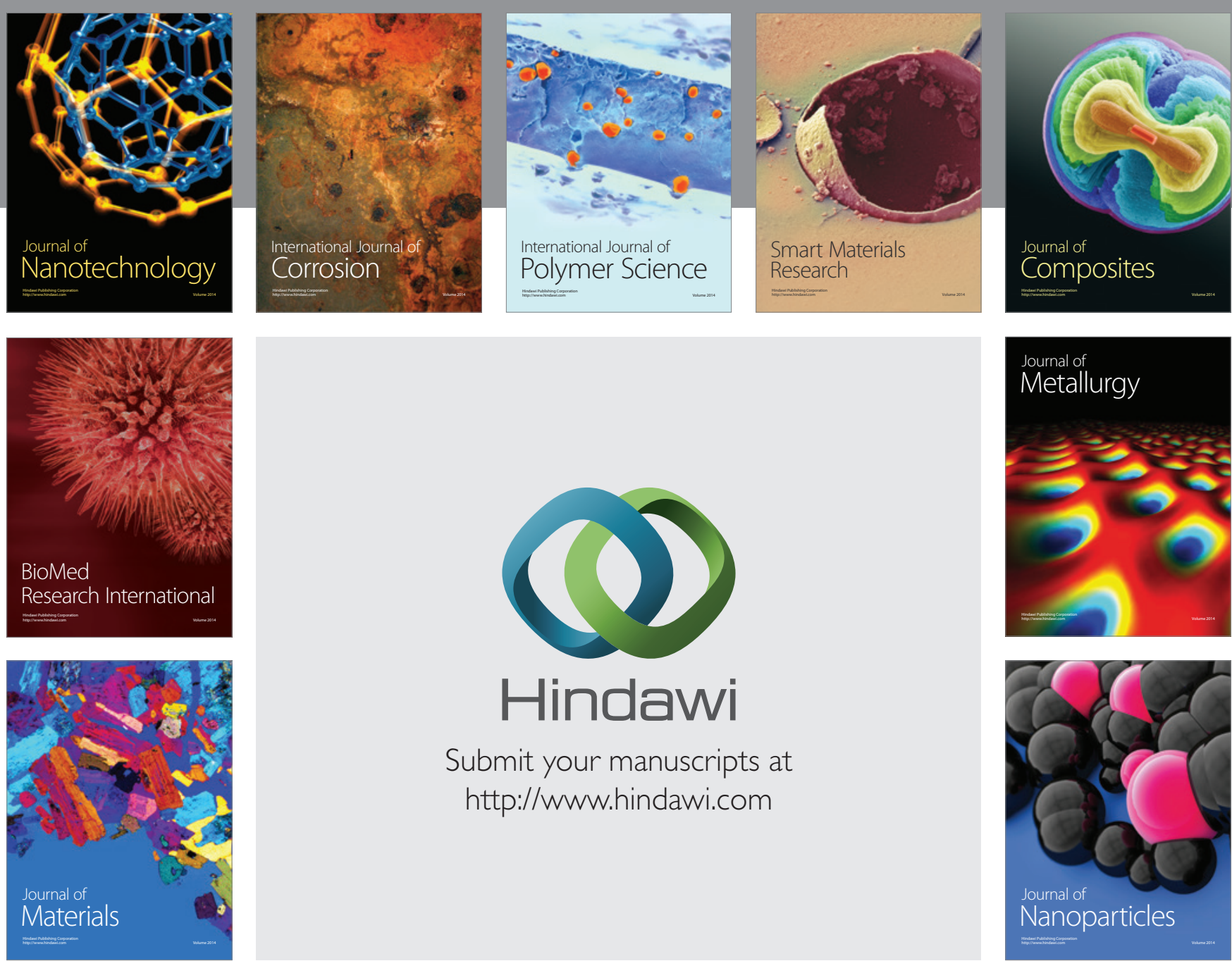

\section{Hindawi}

Submit your manuscripts at

http://www.hindawi.com

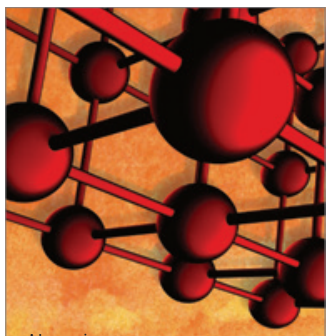

Materials Science and Engineering
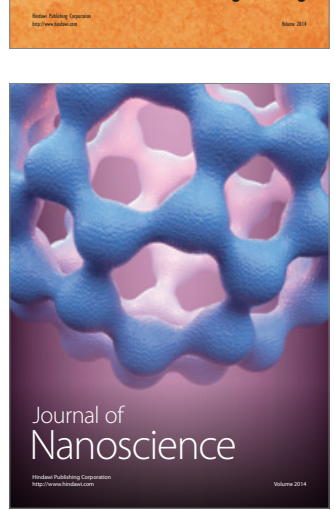
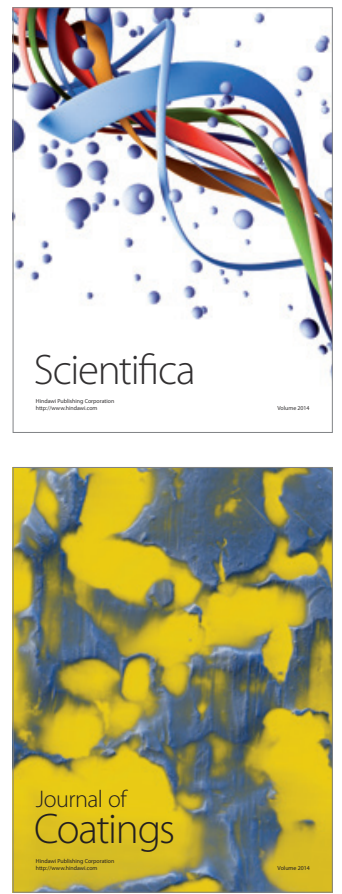


The Scientific World Journal
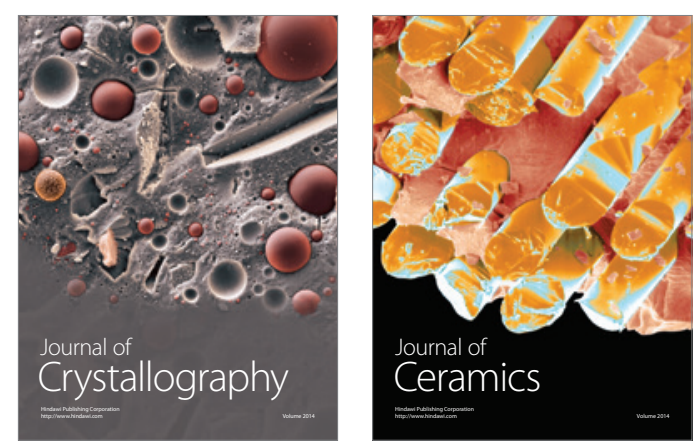
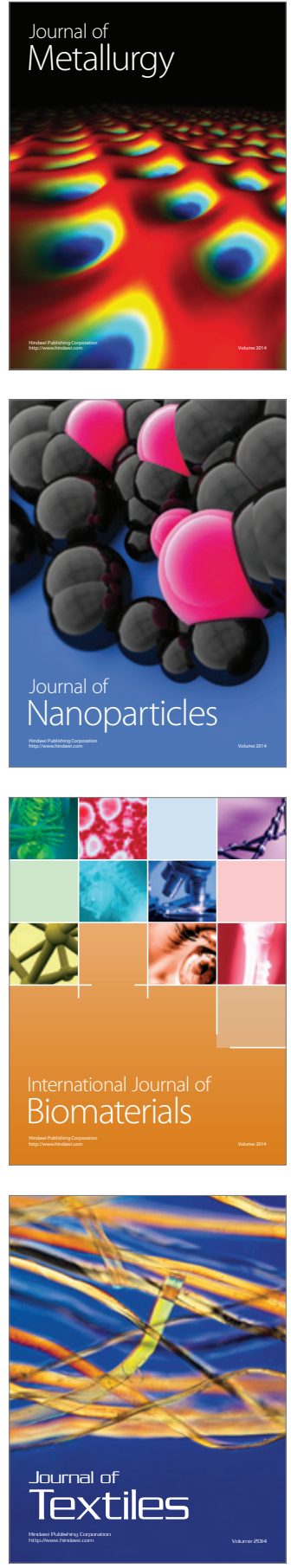